\title{
EVALUATION OF THE SURFACTANT LEACHING FROM ALKALI-ACTIVATED SLAG-BASED COMPOSITES USING SURFACE-TENSION MEASUREMENTS
}

\author{
UPORABA MERITEV POVRŠINSKE NAPETOSTI ZA OCENO \\ IZLUŽEVANJA POVRŠINSKO AKTIVNE SNOVI IZ KOMPOZITOV \\ NA OSNOVI ALKALNO AKTIVIRANE ŽLINDRE
}

\author{
Vlastimil Bílek Jr., Lukáš Kalina, Eva Bartoníčková, Jaromír Pořízka \\ Brno University of Technology, Faculty of Chemistry, Materials Research Centre, Purkyňova 118, 61200 Brno, Czech Republic
}

Prejem rokopisa - received: 2018-07-13; sprejem za objavo - accepted for publication: 2018-09-06

doi:10.17222/mit.2018.148

\begin{abstract}
Nowadays, there are many efforts to reduce $\mathrm{CO}_{2}$ emissions in the building industry, particularly through the use of some alternative binders to those based on Portland cement. One promising group of such binders includes binders based on alkali-activated slag (AAS). However, extensive drying, autogenous shrinkage and the associated cracking prevent AAS from being widely utilized in practice. A possible solution could be the application of shrinkage-reducing admixtures, whose molecules present in the pore solution reduce its surface tension and thus mitigate the AAS shrinkage. However, if AAS comes into contact with water, shrinkage-reducing admixtures can be leached and its effectiveness reduced. This work tries to evaluate the amount of surfactant leached from the AAS-based mortars using a very simple surface-tension (ST) measuring technique. Mortars based on AAS with and without $2 \%$ of PEG varying in molecular weight (MW) were prepared. Waterglass with a $\mathrm{SiO}_{2}$-to- $\mathrm{Na}_{2} \mathrm{O}$ ratio equal to 2.0 was used at a dose corresponding to $8 \% \mathrm{Na}_{2} \mathrm{O}$ with respect to the slag weight. Mortar specimens were prepared and sealed for $24 \mathrm{~h}, 3 \mathrm{~d}$ and $7 \mathrm{~d}$. Then they were demolded and immersed in demineralized water, whose ST was monitored over time. During the early stages (from minutes to a few hours) the ST dropped rapidly, while it remained approximately constant after a few days, which indicates that organic molecules are leached from the AAS specimens very quickly. It was observed that a relatively small fraction of PEGs can be leached out, which indicates that organic molecules are rather bound in the matrix, unable to reduce the ST of the pore solution.
\end{abstract}

Keywords: Alkali-activated slag, polyethylene glycol, leaching, surface tension

Dandanes v gradbeništvu vlagajo velike napore za zmanjšanje emisij $\mathrm{CO}_{2}$, še posebej z uporabo nekaterih Portland cementu alternativnih veziv. Ena od takšnih obetajočih skupin so veziva na osnovi alkalno aktiviranih žlinder (AAS; angl.: alkali-activated slag). Vendar hitro sušenje, avtogeno krčenje, ter s tem povezano pokanje preprečujejo široko uporabo AAS v praksi. Možna rešitev bi lahko bila uporaba dodatkov, ki zmanjšujejo krčenje AAS. Molekule teh dodatkov v porah raztopine zmanjšajo njeno površinsko napetost in tako zmanjšajo krčenje AAS. Če pa je AAS v stiku z vodo, pride do izluževanja dodatkov za zmanjševanje krčenja, pri čemer se zmanjša njihova učinkovitost. V tej raziskavi so avtorji poizkušali oceniti vsebnost izluženega surfaktanta (površinsko aktivne snovi) iz malt na osnovi AAS z uporabo zelo enostavne merilne tehnike merjenja površinske napetosti (ST; angl.: surface tension). Pripravili so malte s spreminjajočo se molekularno maso (MW, angl.: molecular weight) na osnovi AAS brez in z dodatkom 2-\% polietilenglikola (PEG). Uporabili so vodno steklo z razmerjem $\mathrm{SiO}_{2}: \mathrm{Na}_{2} \mathrm{O}=2$, kar odgovarja vsebnosti $8 \% \mathrm{Na}_{2} \mathrm{O}$ glede na maso žlindre. Pripravili so vzorce malt in jih zapečatili oz. jih za 24 $\mathrm{h}, 3 \mathrm{~d}$ in $7 \mathrm{~d}$ zaprli v modele. Nato so modele odprli in malte potopili v destilirano vodo, ter ves čas merili njeno površinsko napetost. V začetnih stadijih opazovanja (nekaj minut do nekaj ur) je površinska napetost vode hitro padala, medtem ko se je po nekaj dneh ustalila, kar pomeni, da so se organske molekule iz vzorcev AAS izlužile zelo hitro. Na osnovi opazovanja so ugotovili, da se lahko izluži le relativno majhen delež PEG. To nakazuje na to, da so organske molekule precej vezane na matrico in niso sposobne zmanjšati površinske napetosti porozne raztopine.

Ključne besede: alkalno aktivirana žlindra, polietilen glikol, izluževanje, površinska napetost

\section{INTRODUCTION}

Alkali-activated materials (AAMs) belong to the group of alternative binders with the potential to enhance the sustainability of the building industry, since they are usually based on secondary raw materials or waste materials, and thus can decrease greenhouse-gas emissions, save energy, etc. The most common sources of aluminosilicate precursors for AAMs are metakaolin, fly ash and granulated blast-furnace slag. The latter, particularly when a waterglass is used for activation, often achieves

*Corresponding author e-mail:

bilek@fch.vut.cz excellent mechanical properties, even at room temperature, that are similar or even better compared to those of Portland-cement-based materials. ${ }^{1}$ However, extensive drying and autogenous shrinkage, resulting in cracking and deterioration of the material properties in general, limit the use of AAS in practice.

Several possible approaches to reduce AAS shrinkage can be found in literature, e.g., the use of mineral admixtures, ${ }^{2,3}$ curing at elevated temperatures ${ }^{4,5}$ or internal curing. ${ }^{6}$ Also, the use of shrinkage-reducing admixtures (SRAs) or generally surface-active substances was reported as being an effective method for AAS shrinkage reduction. ${ }^{7-10}$ In these studies, the beneficial effects of 
SRAs were usually attributed to the changes in pore structure and a reduction of the surface tension, which is, according to capillary-pressure theory, closely related to shrinkage-inducing forces in desiccating (of selfdesiccating) material.

These effects can be, in terms of capillary-pressure theory, illustrated by the Young-Laplace equation (Equation (1)), according to which, for the spherical meniscus inside the pore partially filled with liquid, the pressure difference $\Delta p$ between the liquid and the vapor phase is proportional to the surface tension $\gamma$ and inversely proportional to the pore radius $r ; \cos \theta$ is the wetting angle. Nevertheless, it was summarized ${ }^{11}$ that capillary-pressure theory can explain the drying shrinkage only for pores larger than approximately $10 \mathrm{~nm}$ and a relative humidity higher than $40-50 \%$. Some authors ${ }^{12,13}$ contest the role of capillary action itself and emphasize that the disjoining pressure is at the origin of the shrinkage. The disjoining pressure is a superposition of attractive van der Waals forces, repulsive electric forces and structural forces.

$$
\Delta p=-\frac{2 \gamma}{r} \cos \theta
$$

It is clear (Equation (1)) that if SRAs would act against AAS shrinkage in accordance with the capillarypressure theory, they have to be present in a pore solution and able to adsorb at the liquid-air interface to reduce its energy (surface tension). However, this also means that at least part of this portion of the SRAs can be leached either during the water curing or in contact with the surrounding water in practice, and its effectiveness consequently reduced. These issues were widely studied by Eberhardt ${ }^{14}$ on Portland-cement-based specimens, who observed that $40 \%$ of the studied SRA was associated with hydration products. Such an immobile fraction of the SRA would only be released with the dissolution of the solid matrix itself. Although it cannot reduce the shrinkage via a reduction of the surface-tension decrease, its beneficial effect on the shrinkage can be explained by the disjoining-pressure theory. On the other hand, the mobile fraction of SRA can be removed from the specimen, particularly by diffusion.

Therefore, the purpose of this paper is to pioneer SRA leaching issues for AAS-based mortars. More specifically, the influence of polyethylene glycol's molecular weight, as well as the time of curing before immersion of the specimens in water, on the leaching extent and rate was investigated. The amount of leached PEG was determined using a dynamic surface-tension measurement. Additionally, this study follows our previous one, ${ }^{10}$ where the effect of PEG MW on the drying shrinkage and other properties of AAS mortars and pastes was investigated. In that case, the specimens for drying shrinkage and mechanical properties testing were cured in water for $3 \mathrm{~d}$ and thus the study of the impact of leaching on the obtained results is at hand.

\section{EXPERIMENTAL PART}

\subsection{Materials and mortar composition}

Common ground granulated blast-furnace slag from the Czech production (Kotouč Štramberk, spol. s r.o) with a Blaine fineness of $400 \mathrm{~m}^{2} / \mathrm{kg}$ was activated by sodium waterglass (Vodní sklo, a.s.) with a silicate modulus, i.e., $\mathrm{SiO}_{2}$-to- $\mathrm{Na}_{2} \mathrm{O}$ molar ratio, equal to 2.0. Siliceous sand with a maximum grain size of $2 \mathrm{~mm}$ was used as a fine aggregate. The $\mathrm{Na}_{2} \mathrm{O}$ (introduced into the system by waterglass) to slag ratio, water-to-slag ratio and sand-to-slag ratio were the same for all the prepared mortars: $0.08,0.46$ and 3.0 by weight, respectively. The mortars differed in the organic admixture used. One mortar type was the reference without any other additive (Ref.), while the other five types were modified by polyethylene glycol in the wide range of MW from monomer (ethylene glycol, EG) up to polyethylene glycol of 35,000 g/mole, namely, PEG400, PEG2000, PEG10000 and PEG35000. Their doses were $2 \%$ with respect to the slag weight.

\subsection{Specimen preparation and curing}

The mixing procedure was the same as that prescribed for Portland-cement testing in EN 196-1. After the mixing, mortars were cast into a polypropylene cylindrical container with a diameter of $33 \mathrm{~mm}$ and a height of $70 \mathrm{~mm}$. Then the containers were sealed and kept at $25{ }^{\circ} \mathrm{C}$ until the start of the leaching experiments, i.e., $24 \mathrm{~h}, 3 \mathrm{~d}$ or $7 \mathrm{~d}$. After the desired time, the specimens were demolded and immersed in demineralized water for $7 \mathrm{~d}$, during which time the dynamic surface tension of the leachate was measured. After the $7 \mathrm{~d}$ of leaching, water was exchanged and the ST of the renewed leachate determined after $24 \mathrm{~h}$. The weight of

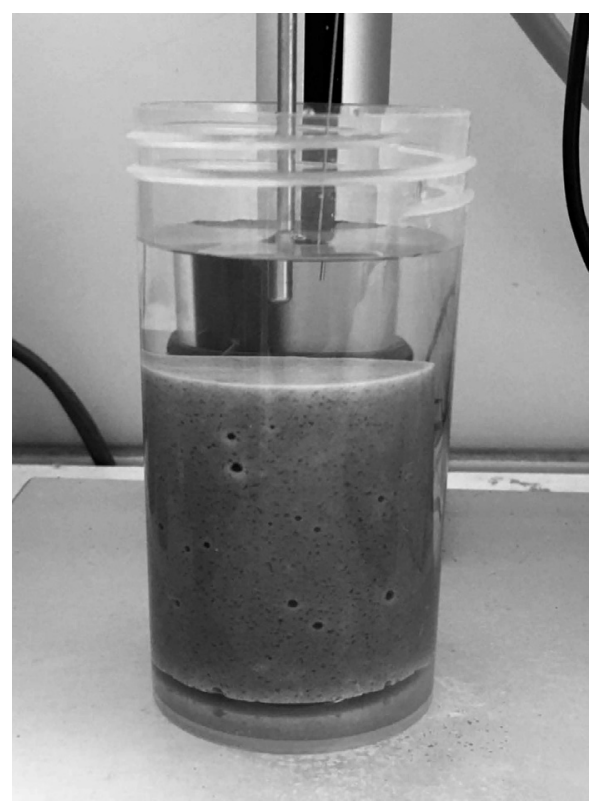

Figure 1: Dynamic surface-tension measurement 
water was the same as the weight of the sample in both cases. One or two specimens for the reference mortar and two or three specimens for the PEG-modified mortars were used for each test series.

\subsection{Dynamic surface-tension measurement}

Before the start of the dynamic ST measurement (Figure 1), leachate in a container containing the specimen was homogenized by gentle gyration. The dynamic ST was determined using a bubble pressure tensiometer BPA 800P (KSV Instruments, Ltd.) after (0.5, 2.5, 5 and 24) $\mathrm{h}$ of leaching, and during the following days, as was mentioned above. A capillary with a diameter of $0.130 \mathrm{~mm}$ was immersed $5 \mathrm{~mm}$ under the leachate surface and the bubble life time was set to $0.1 \mathrm{~s}$. For each time of the test, the values of the ST were recorded every $20 \mathrm{~s}$ during the several minutes and then averaged. Synthetic leachates (see following section) used for the determination of the amount of leached PEG were tested with the same settings.

\subsection{Evaluation of the amount of leached PEG}

The amount of leached PEG was calculated using calibration curves obtained from the dynamic ST measurement of the synthetic leachates containing various amounts of the desired PEG. The synthetic leachates were prepared on the basis of the silicon and sodium content in the leaching water after the first 7 days of leaching, determined using inductively coupled plasma optical emission spectroscopy (ICP-OES). The presence of other elements was neglected due to their very low content in the leachate. Synthetic leachates were prepared by the dilution of waterglass and sodium hydroxide by demineralized water in a volumetric flask, according to Table 1 .

Table 1: Average Si and Na contents in the leachates after each curing time and the amounts of waterglass and $50 \% \mathrm{NaOH}$ used for the synthetic leachates' preparation

\begin{tabular}{|c|c|c|c|c|}
\hline $\begin{array}{c}\text { curing } \\
\text { series }\end{array}$ & $\begin{array}{c}\mathrm{Si} \\
(\mathrm{mg} / \mathrm{L})\end{array}$ & $\begin{array}{c}\mathrm{Na} \\
(\mathrm{mg} / \mathrm{L})\end{array}$ & $\begin{array}{c}\text { waterglass } \\
(\mathrm{g} / \mathrm{L})\end{array}$ & $\begin{array}{c}50 \% \mathrm{NaOH} \\
(\mathrm{g} / \mathrm{L})\end{array}$ \\
\hline $24 \mathrm{~h}$ & 158.6 & 4254 & 1.07 & 11.28 \\
\hline $3 \mathrm{~d}$ & 126.8 & 3461 & 0.857 & 9.19 \\
\hline $7 \mathrm{~d}$ & 118.2 & 2845 & 0.799 & 7.51 \\
\hline
\end{tabular}

\section{RESULTS}

The development of the ST of the leachates is given in Figure 2. It can be seen that except for their monomer, all the PEGs decreased the dynamic ST rapidly within the first $30 \mathrm{~min}$, while this did not change markedly during the following hours and days. On the other hand, all the leachates after the exchange of water reached the same ST values. To assess the amount of leached PEG, calibration curves were determined using synthetic leachate and known additions of PEG. The obtained results are in Figure 3. The amount of leached PEG was determined as its concentration $(w / \%)$ in between the two neighboring points using an interpolation with the assumption that the dependence of ST on the weight concentration is linear between each two measured points and compared with the maximum theoretical PEG concentration $(0.42 \%)$. Using this approach, the mass fraction of easily leachable PEG from the total PEG amount was evaluated (Figure 4). It is clear that an
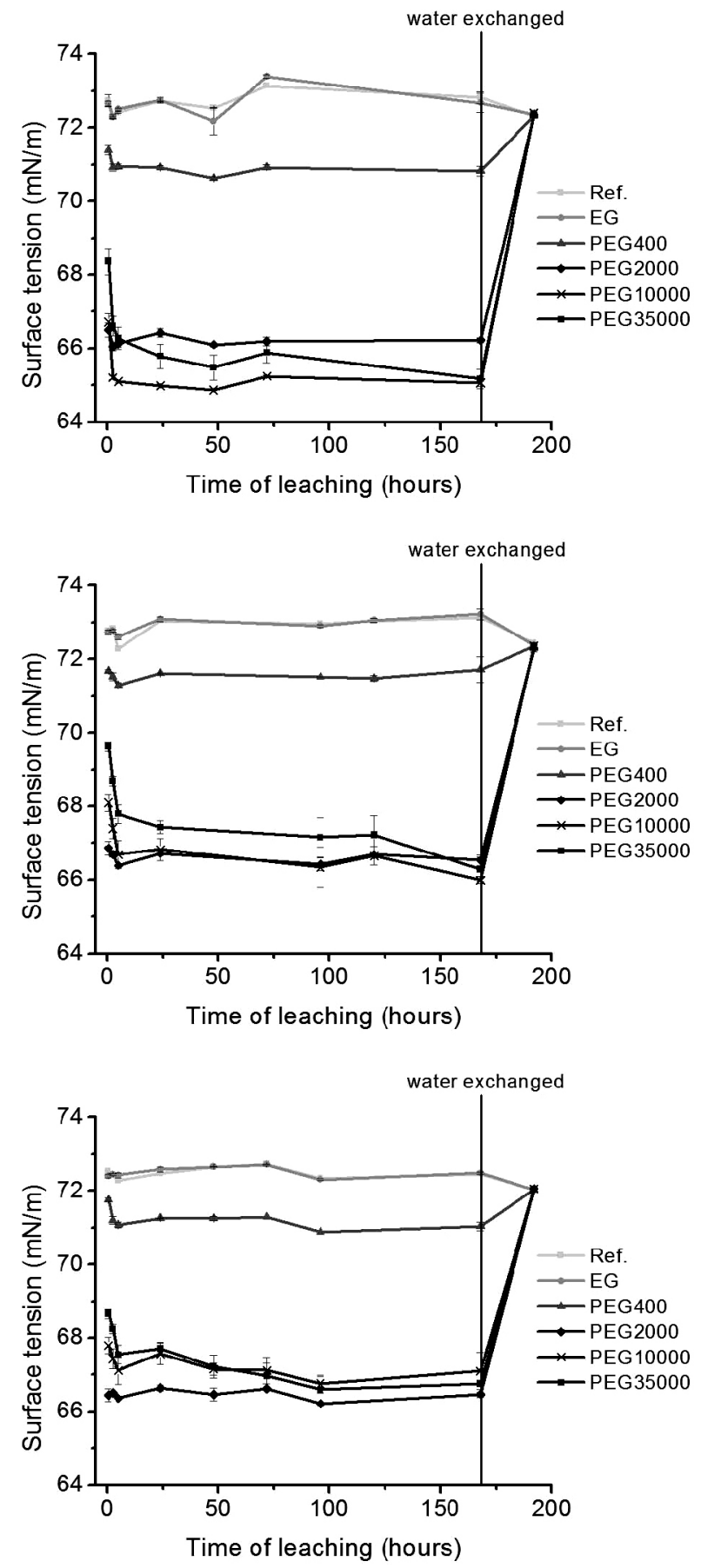

Figure 2: Dynamic surface-tension development of the leaching water after $24 \mathrm{~h}$ (up), $3 \mathrm{~d}$ (in the middle) and $7 \mathrm{~d}$ (down) of curing in autogenous conditions 

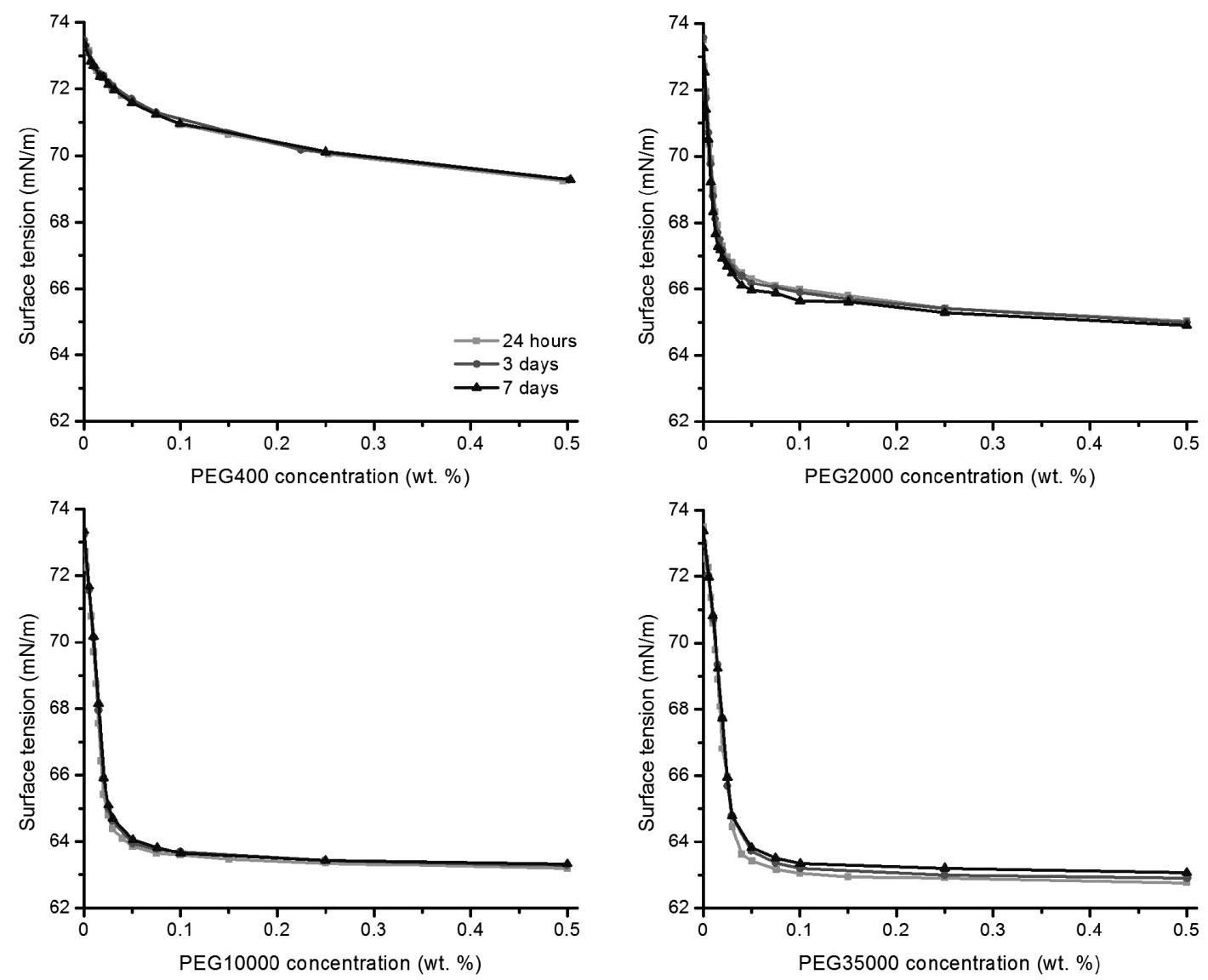

Figure 3: Calibration curves determined using synthetic leachates for each curing time

increase in PEG MW resulted in a decrease of its leachable portion, as it was, e.g., for $24 \mathrm{~h}$ of sealed curing calculated to be $(28,14,5.4$ and 6.3$) \%$ for PEG400, 2000, 10000 and 35000 , respectively. Also, a prolonged time of curing before the leaching experiment, particularly between $24 \mathrm{~h}$ and $3 \mathrm{~d}$, resulted in an increased immobilization of the PEGs. The higher leached amount of PEG400 after $7 \mathrm{~d}$ compared to $3 \mathrm{~d}$ is probably a random error. It also, together with the lengths of the error bars, shows a general disadvantage of the use of ST measurements for a determination of the leached amount of an organic substance. If the ST concentration dependence is flat, i.e., if the substance is not effective in reducing the ST (such as PEG400) or at high surfactant concentrations (above approximately $0.05 \%$ in our cases), even a slight change in the measured ST means a large change in the calculated surfactant concentration. In contrast, the more steep the ST change is, the more precise the results are.

\section{DISCUSSION}

As is well known and as we also reported earlier, ${ }^{10}$ the ST-reducing ability of surfactants depends on their molecular weight. Therefore, it is not possible to estimate the amount of leached PEG only from the ST of the leachate (Figure 2), but the use of calibration curves

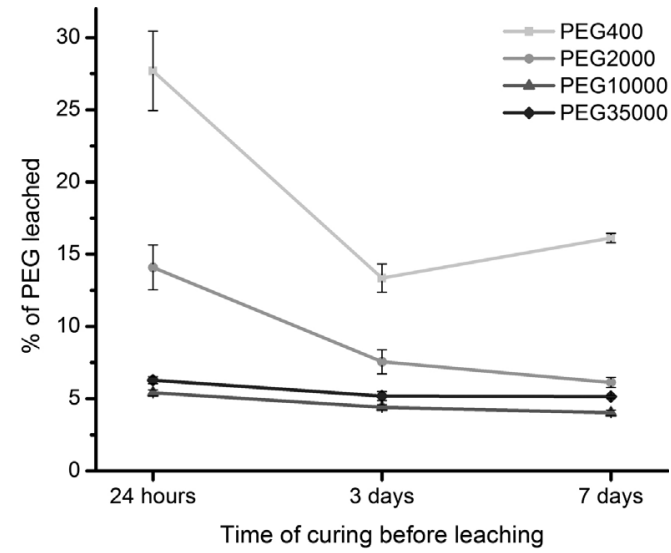

Figure 4: Effect of PEG's molecular weight and time of curing on the amount of PEG leached during the first $7 \mathrm{~d}$ of leaching

(Figure 3) is necessary. However, the presence of other ions in the leachate can affect its ST as well as the performance of organic admixtures, and hence synthetic leachates instead of pure water should be used. In our case, the gradual leaching of ions from the specimens, particularly silicon and sodium (Table 1), plays an important role and can also affect the ST's development. This is probably the reason why the ST of the reference and EG leachate rather increased during ongoing leaching and was usually a few tenths higher than those 
determined for demineralized water. On the other hand, the ST of the second leachate from the Ref and EG specimens was lower compared to that of the first leachate and very close to that of demineralized water, since most of the $\mathrm{Si}$ and $\mathrm{Na}$ leached during the first cycle. The same ST values of the second leachates as for the Ref and EG were observed for all the other PEG specimens, regardless of the time of curing before the start of leaching, which indicates that the total or at least the vast majority of the leachable fraction of PEG had already been leached at the end of the first leaching cycle.

Eberhardt ${ }^{14}$ summarized that the following three mechanisms of leaching can be distinguished: washing out, diffusion and a dissolution process. The very high rate of leaching during its early stages observed in Figure 2 suggests that washing out is the dominating factor in our case. The diffusion at later leaching stages cannot be excluded, since there is likely a competition between the leaching of ions like $\mathrm{Si}$ or $\mathrm{Na}$ and surfactant molecules. Therefore, it can be expected that if the latter is of very limited rate, the former prevails and hence the leaching of the surfactant does not lead to a noticeable $\mathrm{ST}$ reduction. To investigate this in more detail, some other methods of organic-matter detection could be used, e.g., chromatography.

According to Figure 2 and 4, the molecular weight of the used PEG also affected its leaching rate, as well as the amount of leached PEG. While PEG400 and PEG2000 were mostly leached within the first $30 \mathrm{~min}$ or $150 \mathrm{~min}$, the longer PEGs (PEG10000 and PEG35000) gradually decreased the ST up to $5 \mathrm{~h}$. This is likely related to their longer chains, which cannot be transported through the specimen as easily as their shorter analogues. Moreover, the longer molecules are more prone to immobilization in the hydration products, which again contributes to a reduction of their mobile fraction. These issues can also explain the decrease in the amount of mobile fraction with increasing molecular weight and the time of curing before the start of the leaching (Figure 4). Slightly higher leached amounts of PEG35000 compared to PEG10000 would probably be due to their lower and slower solubility in water and activating solution and the consequent lower homogeneity of the specimens, despite efforts to dissolve and homogenize them as well as possible before the slag and sand addition.

The presented findings have a significant impact on the shrinkage behavior. As we have already presented, ${ }^{10}$ MW plays an important role in the shrinkage-reducing ability since EG did not noticeably reduce the drying shrinkage of the AAS mortar, while a further increase in PEG MW had a beneficial effect, particularly up to a molecular weight of $2000 \mathrm{~g} / \mathrm{mole}$. The determination of the amount of SRA that can be leached from the specimen and also the SRA ST-reducing ability allows us to support the discussion from the previous paper and even distinguish between the dominating mechanisms of shrinkage reduction. For shorter molecules like PEG400, only a slight ST-reducing ability, together with a relatively high leaching extent, indicate that neither the reduction of the ST by the mobile phase nor the reduction of the disjoining pressure by the presence of immobile PEG molecules, particularly when water curing is applied, can explain the quite high shrinkage reduction by PEG400. This supports our findings that the shrinkage-reducing ability of the PEG400 lies rather in the changes of the pore structure. On the other hand, the presence of longer PEG molecules, which cannot be easily leached, can act against shrinking via a disjoining-pressure mechanism and thus can be more effective in practical applications. However, a too high MW would also be impractical due to solubility and miscibility issues. For the case of PEGs, a MW of around $2000 \mathrm{~g} / \mathrm{mole}$ (and not more than $10,000 \mathrm{~g} / \mathrm{mole}$ ) would be optimal due to the combination of its relatively high shrinkage-reducing ability and good solubility.

\section{CONCLUSIONS}

This paper investigated the leaching issues associated with AAS-based fine-grained composites. The amount of leached PEGs, depending on their molecular weight and time of curing before the start of the leaching, was determined using dynamic ST measurements.

Both the leaching rate and particularly the leaching extent of the PEGs decrease with their increasing molecular weight. This has a significant impact on the AAS shrinkage performance.

The leaching rate and extent also decrease with a prolonged time of curing.

For practical applications, the use of SRAs based on rather longer polymeric surfactants can be recommended, since they are more effective in reducing the ST, which favors shrinkage reduction according to the capillary-pressure theory, while its increased immobile fraction can act against shrinkage in terms of the disjoining-pressure theory. Moreover, a reduced leaching extent is important from the environmental viewpoint. On the other hand, for molecules that are too long, miscibility or solubility issues should also be kept in mind.

\section{Acknowledgment}

This outcome was achieved with the financial support within the project: Materials Research Centre at FCH BUT- Sustainability and Development, REG LO1211, with financial support from the National Program for Sustainability I (Ministry of Education, Youth and Sports) and GA17-03670S "Development of shrinkage reducing agents designed for alkali activated systems", with financial support from the Czech science foundation. 


\section{REFERENCES}

${ }^{1}$ F. G. Collins, J. G. Sanjayan, Workability and mechanical properties of alkali activated slag concrete, Cem. Concr. Res., 29 (1999) 3, 455-458, doi:10.1016/S0008-8846(98)00236-1

${ }^{2}$ N. K. Lee, J. G. Jang, H. K. Lee, Shrinkage characteristics of alkaliactivated fly ash/slag paste and mortar at early ages, Cem. Concr. Compos., 53 (2014), 239-248, doi:10.1016/j.cemconcomp.2014. 07.007

${ }^{3} \mathrm{~S}$. Aydin, A ternary optimisation of mineral additives of alkali activated cement mortars, Constr. Build. Mater., 43 (2013), 131-138, doi:10.1016/j.conbuildmat.2013.02.005

${ }^{4}$ N. Marjanovic, M. Komljenovic, Z. Bascarevic, V. Nikolic, R. Petrovic, Physical-mechanical and microstructural properties of alkali-activated fly ash-blast furnace slag blends, Ceram. Int., 41 (2015) 1, 1421-1435, doi:10.1016/j.ceramint.2014.09.075

${ }^{5}$ T. Bakharev, J. G. Sanjayan, Y. B. Cheng, Effect of elevated temperature curing on properties of alkali-activated slag concrete, Cem. Concr, Res., 29 (1999) 10, 1619-1625, doi:10.1016/S00088846(99)00143-X

${ }^{6}$ A. R. Sakulich, D. P. Bentz, Mitigation of autogenous shrinkage in alkali activated slag mortars by internal curing, Mater. Struct., 46 (2013) 8, 1355-1367, doi:10.1617/s11527-012-9978-z

${ }^{7}$ M. Palacios, F. Puertas, Effect of shrinkage-reducing admixtures on the properties of alkali-activated slag mortars and pastes, Cem. Concr. Res., 37 (2007) 5, 691-702, doi:10.1016/j.cemconres.2006. 11.021
${ }^{8}$ C. Bilim, O. Karahan, C. D. Atis, S. Ilkentapar, Influence of admixtures on the properties of alkali-activated slag mortars subjected to different curing conditions, Mater. Des., 44 (2013), 540-547, doi:10.1016/j.matdes.2012.08.049

${ }^{9}$ L. Kalina, V. Bilek, E. Bartonickova, J. Krouska, Polypropylene glycols as effective shrinkage-reducing admixtures in alkali-activated materials, ACI Mater. J., 115 (2018) 2, 251-256, doi:10.14359/ 51701099

${ }^{10}$ V. Bilek, L. Kalina, R. Novotny, Polyethylene glycol molecular weight as an important parameter affecting drying shrinkage and hydration of alkali-activated slag mortars and pastes, Constr. Build. Mater., 166 (2018), 564-671, doi:10.1016/j.conbuildmat.2018.01. 176

${ }^{11}$ P. C. Aïtcin, R. J. Flatt, Science and Technology of Concrete Admixtures, $1^{\text {st }}$ ed., Woodhead Publishing: Sawston, Cambridge, UK 2015

${ }^{12}$ F. H. Wittman, Heresies on shrinkage and creep mechanisms, Proc. of the $8^{\text {th }}$ Inter. Conf. on Creep, Shrinkage and Durability of Concrete and Concrete Structures, Japan 2009

${ }^{13}$ F. Beltzung, F. H.Wittmann, Role of disjoining pressure in cement based materials, Cem. Concr. Res., 35 (2005) 12, 2364-2370, doi:10.1016/j.cemconres.2005.04.004

${ }^{14}$ A. B. Eberhardt, On the Mechanisms of Shrinkage Reducing Admixtures in Self Consolidating Mortars and Concretes, Ph.D. Thesis, Bauhaus Universität Weimar, Weimar, Germany 2011 